DIGITAL COMMONS

@ UNIVERSITY OF SOUTH FLORIDA

\section{ABO: Interactive Journal for Women in the Arts, 1640-1830}

\title{
Madam Britannia: Women, Church, and Nation, 1712-1812, by Emma Major
}

\author{
Kathryn Stasio \\ Saint Leo University, kathryn.stasio@saintleo.edu
}

Follow this and additional works at: https://digitalcommons.usf.edu/abo

Part of the Dramatic Literature, Criticism and Theory Commons, Educational Methods Commons, Feminist, Gender, and Sexuality Studies Commons, and the Literature in English, British Isles Commons

\section{Recommended Citation}

Stasio, Kathryn (2013) "Madam Britannia: Women, Church, and Nation, 1712-1812, by Emma Major," ABO: Interactive Journal for Women in the Arts, 1640-1830: Vol.3: Iss.1, Article 11.

http://dx.doi.org/10.5038/2157-7129.3.1.11

Available at: https://digitalcommons.usf.edu/abo/vol3/iss1/11

This Reviews is brought to you for free and open access by Digital Commons @ University of South Florida. It has been accepted for inclusion in ABO: Interactive Journal for Women in the Arts, 1640-1830 by an authorized administrator of Digital Commons @ University of South Florida. For more information, please contact digitalcommons@usf.edu. 


\section{Madam Britannia: Women, Church, and Nation, 1712-1812, by Emma Major}

\section{Keywords}

religion, Madam Britannia, women, public sphere, eighteenth century

\section{Creative Commons License}

\section{(c) $($ ) $\odot$}

This work is licensed under a Creative Commons Attribution-No Derivative Works 3.0 License. 
Emma Major. Madam Britannia: Women, Church, and Nation, 1712-1812. New York: Oxford UP, 2012. xii-371pp. Bibliography. Index. ISBN: 978-0-19-969937-7.

Reviewed by Kathryn Stasio

Saint Leo University

Emma Major's ambitious and successful Madam Britannia explores the ubiquitous and paradoxical image of Madame Britannia in order to understand women's roles in a nation that partially defined itself via its official, national religion. Linking patriotism with the Church of England created space for women in the public sphere. Major notes early on that her work goes beyond the conventional canon and much closer to a sense of what eighteenth-century readers would have called literature, including not just novels and poetry but sermons, histories, political tracts, and conduct manuals. This is both a strength and limitation of the book. Those looking for extensive, in-depth readings of individual texts will not find that here, but Major gives insight across a breadth of texts and substantial support for her claims. Importantly, she highlights religion, an integral part of the Age of Reason that scholars are finally, thankfully, exploring with the attention it deserves.

Major lays out her claims and warrants well in her introduction, explaining her choice of Madam Britannia as iconography worth studying as an emblem of Britain. This ubiquitous figure, featured even on coins, "is often at war with herself, representing clashing identities and competing histories, an anxious embodiment of the battle between history and modernity, and nation and state" (6). Major notes that her dates, 1712-1812, frame the diverse and complex ideas about femininity that mark the eighteenth century where "[e]nlightenment historians developed conjectural histories that placed women at the centre of civilisation. Women's religion, conversation, and social practice thus had a new resonance in this new, self-consciously civilised age" (1). She also introduces readers to a central figure in her book, Elizabeth Montagu, who stands as an exemplary eighteenth-century woman. Through Montagu, her correspondence with others (including with her sister, the author of Millenium Hall), and nods to canonical figures such as Samuel Richardson, Major demonstrates how the golden mean-in contrast to the extremes of Dissenters and Catholics — connects to religion and patriotism for the British.

Opening chapters give a history of Britannia and explore the exemplary figures of Montagu and Catherine Talbot, women "participating in the public life of a Christian nation" (99). Britannia at times embodied all of Britain but often was associated solely with England. She also was linked to Queen Elizabeth I who stood as an icon of the golden mean thanks to the notion that she mediated between the extreme Puritans and Catholics, figures who also were personified as women, the sloven and the harlot respectively. The book includes pictures and thorough explications as Major traces the weakening of Madam Britannia by the end of the century when the French Revolution became associated with female imagery. Both Montagu and Talbot, through various roles but particularly those associated with the church, become associated with Madam Britannia, with Montagu self-consciously identifying herself with Queen Elizabeth. Montagu strove to achieve the golden mean as she negotiated feminine humility with overwhelming praise found in letters, dedications, poetry, and prefaces. Like Montagu, Talbot fashioned a sense of the golden mean, attempting to find the ideal combination of personal piety with sociability, writing extensively on conversation as a place where evangelicalism and the 
social could meet. The section on Talbot offers helpful insight on journaling and letter writing during the period and how Talbot saw her own journals as having a pedagogic function.

Chapter Three does offer a more extensive reading of a canonical text, Richardson's Sir Charles Grandison where the protagonist needs "the validation provided by the supporting female characters, whose exemplary virtues affirm not only the hero but the version of Britishness that he represents," but Grandison also is threatened by the "excessive exemplariness" of the women (100), a fear that Richardson had in his personal life (102). Major ties this to shifting ideas of masculinity, as men of commerce attempted to enter the public realm in a society still led by substantial landowners, and to contemporary ideas about Protestant nunneries. Richardson's correspondence is peppered with references to such nunneries, hospitals for penitent women, and polygamy; "the segregation of women is necessary for the performance of his model of modern virtuous masculinity; in many ways, Richardson's proposals for Protestant nunneries and polygamy are the price to be paid for Sir Charles's heroism" (115). Major traces a similar pattern in Thomas Amory's The Life of John Buncle.

Chapter Four treats Methodism, an important subject for Major's argument given the association of Methodism with women, who made up the majority of its membership and were granted leadership roles, as well as Methodism's association with bodily experience. The Church of England subsequently needed its own female iconography to distinguish itself from the enthusiasts, as Methodists were called. Major gives an accurate reading of anti-Methodist print attacks, notably John Langhorne's Letters on Religious Retirement, Melancholy, and Enthusiasm (1762) where Langhorne, who is explicitly addressing women, falsely accuses Methodists of being devoted too much to private devotion, claiming only the Church of England engaged in public charity, thus privileging public piety and creating a public space for women. Major includes readings of Samuel Foote, Hogarth, and Sarah Scott calling Millenium Hall an "English fictional sermon on Anglican femininity ... that reflects Scott's preference for practical piety" (155).

Chapter Five returns to Montagu and how politeness becomes a way for Montagu and her circle to define "themselves against an allegedly treasonous, Dissenting middling class and the ubiquitous mob" (167). Major explains how the Sunday school movement, in which Montagu was active, attempted to reform manners and to "promote a less radical Protestant citizenship" (174). She further ties these ideas to the new centrality of the political to Montagu and her circle and returns to concerns about the amount and quality of socializing for women as they create the golden mean for themselves in contrast to the Puritan recluses and Catholic socialites. "Conversation, like femininity and commerce, is a marker of progress and polish, and of corruption and decay. The negative effects of too much female company and conversation are the same as those of too much commerce: all lead to effeminacy" (197).

The last few chapters trace the decline of Madam Britannia from the fusion of civilization and religion of the 1770 s and 1780 s to the 1790 s, which "saw a splintering and hardening of denominational identities that made the polite sociability of the more accommodating 1770s seem a remote impossibility" (297). In addition to continuing to trace Montagu and her circle, who, in their old age saw not only their own deaths approaching but feared for the death of the nation, Major includes Laetitia Barbauld and Hannah More. Major describes the apocalyptic 
language and reads texts in context with visual representations, highlighting the use of Biblical imagery and how the same Biblical texts were appropriated by conservatives and liberals.

"Reading religion back into texts of the period reveals to how great an extent anti-revolutionaries saw themselves as acting within a religious, moral battle" (234-5). In an epilogue, Major explores the legacy of Madam Britannia, discussing her as statuary in Westminster Abbey and St. Paul's Cathedral as well as her use in the mourning of Admiral Nelson.

Madam Britannia is sweeping but only in the best sense of the word. The writing is clear, the ideas relevant, and the research admirable. Such engagement with wide sweeping primary texts is demanding work, and readers will appreciate Major for doing so with such aplomb. 